\title{
Electrodeposited $\mathrm{WO}_{3} / \mathrm{Au}$ Photoanodes for Photoelectrochemical Reactions
}

(Pengelektroendapan Fotoanod $\mathrm{WO}_{3} / \mathrm{Au}$ untuk Tindak Balas Fotoelektrokimia)

\author{
Lorna Jeffery MingGU*, Nurul Akmal JaAfar, Kim Hang NG, KhuZaimah Arifin \& Rozan Mohamad \\ YUNUS
}

\begin{abstract}
This work aims to study the effect of gold (Au) loading on the photoelectrochemical behavior of tungsten trioxide ( $\left.\mathrm{WO}_{3}\right)$ photoelectrodes. The $\mathrm{WO}_{3}$ film has been fabricated via electrodeposition method with constant potential on fluorine doped tin oxide (FTO) glass substrate. The Au nanoparticle loading on $\mathrm{WO}_{3}$ films surface was also prepared by constant potential electrodeposition. Due to the small amount of Au loading, the band gap values of the plasmonized $\mathrm{WO}_{3}$ remained around $2.6 \mathrm{eV}$. However, during the photoelectrochemical analysis, the photoactivity of the plasmonized $\mathrm{WO}_{3}$ photoelectrodes improved $>100 \%$ with a minimal amount of Au loading compared to the pristine WO . The photocurrent generation was further enhanced with the presence of organic donors (methanol and formic acid). The photocurrent achieved $3.74 \mathrm{~mA} / \mathrm{cm}^{2}$ when $1.0 \mathrm{M}$ of formic acid was added. Plausible charge transfer mechanism was suggested.
\end{abstract}

Keywords: Au nanoparticles; electrodeposition; photoelectrochemical; waste degradation; $\mathrm{WO}_{3}$ films

ABSTRAK

Kajian ini bertujuan untuk menguji kesan muatan aurum (Au) terhadap perilaku fotoelektrokimia fotoelektrod tungsten trioksida $\left(\mathrm{WO}_{3}\right)$. Filem $\mathrm{WO}_{3}$ telah dihasilkan melalui kaedah elektroendapan potensi malar ke atas kaca bersalut timah oksida terdop florin (FTO). Nanopartikel Au dimendapkan ke atas permukaan filem WO dengan kaedah elektroendapan potensi malar. Jurang tenaga $\mathrm{WO}_{3}$ berplasmon kekal sekitar $2.6 \mathrm{eV}$ disebabkan muatan Au yang sangat kecil. Namun begitu, semasa analisis fotoelektrokimia, fotoaktiviti fotoelektrod $\mathrm{WO}_{3}$ berplasmon telah meningkat $>100 \%$ dengan muatan Au yang minimum berbanding $\mathrm{WO}_{3}$ tulen. Penjanaan fotoarus telah ditingkatkan lagi dengan penambahan penderma organik (metanol dan asid formik). Fotoarus telah mencapai $3.74 \mathrm{~mA} / \mathrm{cm}^{2}$ apabila 1.0 M asid formik ditambahkan. Mekanisma pemindahan cas yang munasabah juga dicadangkan.

Kata kunci: Elektroendapan; filem $\mathrm{WO}_{3}$; fotoelektrokimia; nanopartikel Au; penguraian sisa

\section{INTRODUCTION}

Fossil fuel consumption is the main source of carbon dioxide and other greenhouse gases which contributes to global warming. The emission of greenhouse gases keeps increasing due to the increasing population and demand for high quality of life. In the search for another energy from renewable sources, hydrogen is the most promising alternative to replace the current use of fossil fuels (Yan et al. 2017). Different from fossil fuel as an energy source, hydrogen is an energy carrier and its source exists in many different compounds such as methane and water. Despite this, hydrogen carries high energy in its molecules more than in coal and gasoline (Alenzi et al. 2010). Hydrogen oxidation in fuel cell produces energy of about $\sim 140 \mathrm{kJg}^{-1}$ meanwhile consumption of gasoline via conventional combustion generates only $\sim 43 \mathrm{kJg}^{-1}$ (Kwong et al. 2012). Moreover, the consumption of hydrogen gas in fuel cell is environmentally friendly as water is the only byproduct (Wang et al. 2011). However, at present, the hydrogen gas is mainly produced via steam reforming process. This process requires huge amount of energy and also gives out carbon dioxide as the byproduct (Zhang $\&$ Tang 2012). Hence, generation of hydrogen gas from renewable sources is gaining new urgency.

Photoelectrochemical (PEC) hydrogen production is an ideal method to replace the current method. Since the first report by Fujishima and Honda (1972), semiconductor materials such as $\mathrm{TiO}_{2}$ have become the main interest in this field. Recently, many other semiconductors have been studied, such as $\mathrm{WO}_{3}, \mathrm{ZnO}, \mathrm{Fe}_{2} \mathrm{O}_{3}, \mathrm{BiVO}_{4}$ and $\mathrm{Cu}_{2} \mathrm{O}$ (Chen et al. 2020a; Ng et al. 2018). The design and fabrication of highly efficient photocatalyst for this 
application is a very challenging task. The selection of semiconductors must fulfill several criteria such as: small band gap energy to absorb visible light; suitable band edges (the conduction band should be more negative than the hydrogen reduction potential and the valence band should be more positive than water oxidation potential); high charge mobility and long charge carrier diffusion length; and strong catalytic activity; good stability; and sustainability and low cost (Li \& Wu 2015). Though not all criteria were satisfied, tungsten trioxide $\left(\mathrm{WO}_{3}\right)$ becomes our interests and it is a great semiconductor material to replace the commonly used $\mathrm{TiO}_{2}$. It is an n-type semiconductor with strong resistance against photocorrosion (Zhang et al. 2011). Also, the band gap energy value of $\mathrm{WO}_{3}$ is much smaller $(2.5-2.8 \mathrm{eV}$ ) (Han et al. 2012; Lianos 2011) compared to $\mathrm{TiO}_{2}(3.0-3.2 \mathrm{eV})$ (Lee \& Jo 2016; Zhu et al. 2016), which allows the $\mathrm{WO}_{3}$ to absorb the blue part of visible light and the ultraviolet region in the solar spectrum. Theoretically, the solar-tohydrogen efficiency of $\mathrm{WO}_{3}$ is $4.8 \%$, which is much higher compared to $\mathrm{TiO}_{2}(1.3 \%)$ (Li et al. 2013a).

Though $\mathrm{WO}_{3}$ has fulfilled most of the criteria, the photocurrent generation of this material during photoelectrochemical water splitting remained unsatisfied. Thus, several modifications techniques on the photocatalyst were reported, including doping ( $\mathrm{Ng}$ et al. 2013; Sheng et al. 2017), layers or junction (Minggu et al. 2014; Zhu et al. 2013), nanostructure fabrication (Chakrapani et al. 2009), and noble metal loading on the photocatalyst surface (Hu et al. 2016; Jun et al. 2020; Lui et al. 2019; $\mathrm{Ng}$ et al. 2017). Recently, the loading of noble metals (such as $\mathrm{Pt}, \mathrm{Ag}$ and $\mathrm{Au}$ ) has received much interest as minimal amount of the noble metals loaded on the surface of the photocatalyst able to increase the photoactivity significantly. The noble metal is known to efficiently trapping electrons which inhibit the recombination of the charges and assist in charge transfer (Li et al. 2013b; Nishanthi et al. 2015; Verma et al. 2013). Besides, the said noble metals also improved the photoeletrochemical activity and some works reported that noble metals can extend the absorption of light of largeband-gap semiconductors $\left(\mathrm{TiO}_{2}\right.$ and $\left.\mathrm{ZnO}\right)$ to visible range due to surface plasmon resonance effect (SPR) in which the free valence electrons in the noble metal nanoparticles were excited by visible light (Haro et al. 2014; Jana et al. 2014; Peerakiatkhajohn et al. 2015). Ag is the most commonly used noble metal in this photoelectrochemical applications as it is lower cost compared to the others. However, recently Au have been extensively studied due to its higher work function and it demonstrates a higher atmospheric stability and resistance towards oxygen (Chen et al. 2020b; Verma et al. 2016).

Besides, the $\mathrm{WO}_{3}$ is also an active photocatalyst used in photodegradation of organic compounds under light irradiation (Aslam et al. 2014; Raptis et al. 2017). Since the degradation of the organic compounds is thermodynamically more favorable compared to water, these organic materials can act as electron donors at the electrode/electrolyte interface, which inhibit the photocharges electron-holes recombination in the aqueous electrolyte (Tee et al. 2017). Such donors include small chain organic acids and alcohols such as methanol and glycerol. The photocurrent was enhanced during PEC process as the donor efficiently suppressed the recombination of electron-holes, resulting in higher $\mathrm{H}_{2}$ production rate.

In this work, we report the photoelectrochemical (PEC) properties of $\mathrm{Au}$ loaded $\mathrm{WO}_{3}$ film fabricated by electrodepositon method with contant-potential. The introduction of $\mathrm{Au}$ nanoparticles on $\mathrm{WO}_{3}$ films surface have greatly increased the PEC activities in the electrolyte. Meanwhile, the presence of organic compounds in the electrolyte further enhance the photocurrent generation.

\section{EXPERIMENTAL DETAILS}

\section{MATERIALS}

Sodium tungstate dihydrate $\left(\mathrm{Na}_{2} \mathrm{WO}_{4} \cdot 2 \mathrm{H}_{2} \mathrm{O}\right.$, Sigma Aldrich), hydrogen peroxide $\left(\mathrm{H}_{2} \mathrm{O}_{2}\right.$, Merck), nitric acid $\left(\mathrm{HNO}_{3}\right.$, Merck), gold chloride solution $\left(\mathrm{HAuCl}_{4}, \mathrm{Sigma}\right.$ Aldrich), methanol ( $\mathrm{CH}_{3} \mathrm{OH}$, Merck), formic acid (CHOOH, Sigma Aldrich), sodium sulfate $\left(\mathrm{Na}_{2} \mathrm{SO}_{4}\right.$, Sigma Aldrich), acetone $\left(\mathrm{C}_{3} \mathrm{H}_{6} \mathrm{O}\right.$, Merck) and ethanol $\left(\mathrm{C}_{2} \mathrm{H}_{5} \mathrm{OH}\right.$, Merck) were used as received, and doubly distilled water was used along the experiment.

\section{FABRICATION OF $\mathrm{WO}_{3}$ FILMS WITH AU LOADING}

Prior to preparation of $\mathrm{WO}_{3}$ films, the fluorine-doped-tin oxide (FTO) glass was sonically cleaned with ethanol, acetone and distilled water sequentially for $5 \mathrm{~min}$ and dried at room temperature. Then, the $\mathrm{WO}_{3}$ films were electrodeposited onto the FTO glass in a three-electrode system where FTO glass is connected as working electrode, platinum foil as counter electrode, and saturated calomel electrode (SCE) as reference electrode. These electrodes were placed in a beaker with equal distance in the acidic peroxy-tungstate solution that serves as the electrolyte. The potential was fixed at $-0.6 \mathrm{~V}$ (vs. SCE) with a duration of $20 \mathrm{~min}$. The resulting films were rinsed with copious amount of doubly distilled water to remove clogged ions and dried at room temperature. After that, the films were calcined in furnace at $350{ }^{\circ} \mathrm{C}$ for $30 \mathrm{~min}$ and cut into small size. These small pieces of $\mathrm{WO}_{3}$ films were used as a substrate for $\mathrm{Au}$ nanoparticle deposition via constant-potential electrodeposition method, in a three electrode-system containing $0.05 \mathrm{mM}$ of $\mathrm{HAuCl}_{4}$ solution. The Au deposition was carried out under constant 
potential of $-0.245 \mathrm{~V}$ (vs. SCE) for $1,5,10$, and $15 \mathrm{~s}$. The resulting films were rinsed with doubly distilled water and dried at room temperature. Lastly, they were made into photoelectrodes by connecting the copper wires onto the FTO glass using conductive silver paint, as mentioned in previous study (Minggu et al. 2010). They were left for overnight before the epoxy resin was applied to enhance the connection. Glass tube was installed to protect the wires from the surrounding electrolyte solution. The photoelectrodes were sealed properly as the exposed silver paste and FTO glass may cause the undesired side reactions.

\section{CHARACTERIZATION}

Morphological study of the samples was carried out using field emission scanning electron microscope (FESEM, Merlin) and the chemical composition was studied using energy dispersive X-ray analysis (EDX). Meanwhile, the optical characterization was carried out using a UV-Vis spectrophotometer (PerkinElmer Lambda 35). The absorption spectra were used for Tauc plot and the calculation involved is based on relation below (Hong et al. 2011):

$$
(\alpha h v)^{\mathrm{n}}=\mathrm{A}\left(\mathrm{h} v-\mathrm{E}_{\mathrm{g}}\right)
$$

where $\alpha$ is the optical absorption coefficient; hv is the light energy; $\mathrm{A}$ is a constant; $\mathrm{E}_{\mathrm{g}}$ is the optical band gap. The value of $\mathrm{n}=0.5$ for indirect band gap and $\mathrm{n}=2$ for direct band gap materials. Because of $\mathrm{WO}_{3}$ has an indirect band gap, Tauc plot of $(\alpha h v)^{0.5}$ was plotted and its extrapolation on $x$ intercepts gives the optical band gap value.

\section{PHOTOELECTROCHEMICAL ANALYSIS}

The photoelectrochemical measurement of the films were performed in a conventional three-electrode system with annealed $\mathrm{WO}_{3}$ or $\mathrm{WO}_{3} / \mathrm{Au}$ photoelectrode as the working electrode, platinum as counter electrode, and SCE as reference electrode. A supporting electrolyte of $0.5 \mathrm{M} \mathrm{Na}_{2} \mathrm{SO}_{4}$ solution was used to facilitate the ionic transfer efficiently. Prior to photocurrent measurement, the photoelectrodes were immersed in the supporting electrolyte and purged with nitrogen gas for $30 \mathrm{~min}$. The scan rate was set as $0.05 \mathrm{~V} / \mathrm{s}$ throughout the experiments. The analysis was carried out under Xenon lamp as simulated solar light source with light intensity of $100 \mathrm{~mW} / \mathrm{cm}^{2}$. Also, methanol and formic acid were added into the system as organic sacrificial donor during the tests.

\section{RESULTS AND DISCUSSION}

Figure 1 shows the morphology and the cross-sectional profiles of the $\mathrm{WO}_{3}$ and $\mathrm{WO}_{3} / \mathrm{Au}$ photoelectrodes. The $\mathrm{WO}_{3} / \mathrm{Au}(1 \mathrm{~s})$ and $\mathrm{WO}_{3} / \mathrm{Au}(5 \mathrm{~s})$ photoelectrodes show similar morphology to the typical dense $\mathrm{WO}_{3}$ prepared via electrodeposition method. However, the electrodeposited $\mathrm{Au}$ nanoparticles were not observable on the $\mathrm{WO}_{3}$ surface. To determine the presence of $\mathrm{Au}$ nanoparticles on the $\mathrm{WO}_{3}$ surface, EDX analysis (Figure 2) was carried out. Based on the results, the Au peaks are detected but not quantifiable in wt. \%. This indicated that the $\mathrm{Au}$ nanoparticles were deposited onto the surface of $\mathrm{WO}_{3}$ film in a very small amount. In our other study, the $\mathrm{Au}$ is visible when using higher $\mathrm{Au}$ concentration in the electrodeposition solution ( $\mathrm{Ng}$ et al. 2017). The elemental mapping shows that the $\mathrm{Au}$ was distributed homogeneously across the surface of $\mathrm{WO}_{3}$.
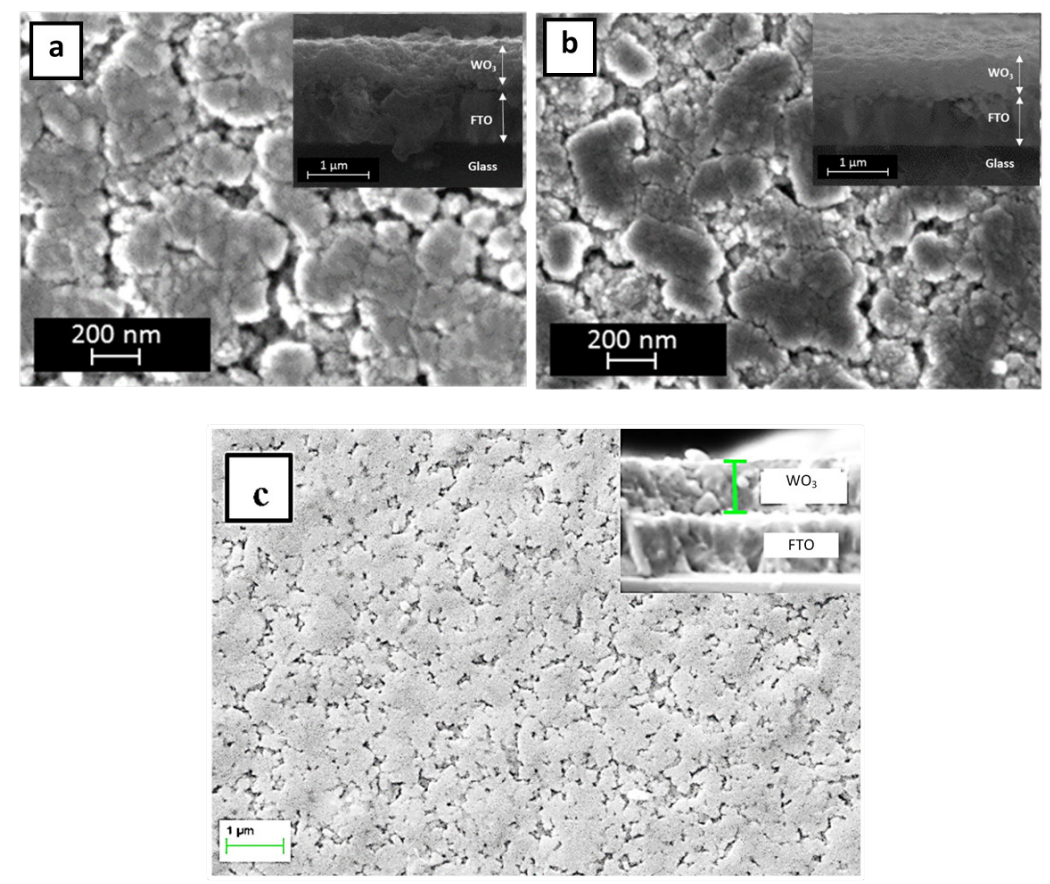

FIGURE 1. FESEM images of (a) $\mathrm{WO}_{3} / \mathrm{Au}(1 \mathrm{~s})$ and (b) $\mathrm{WO}_{3} / \mathrm{Au}(5 \mathrm{~s})$ at $30 \mathrm{kx}$ magnification and (c) $\mathrm{WO}_{3}$ at $10 \mathrm{kx}$ magnification with their cross-sectional profiles 

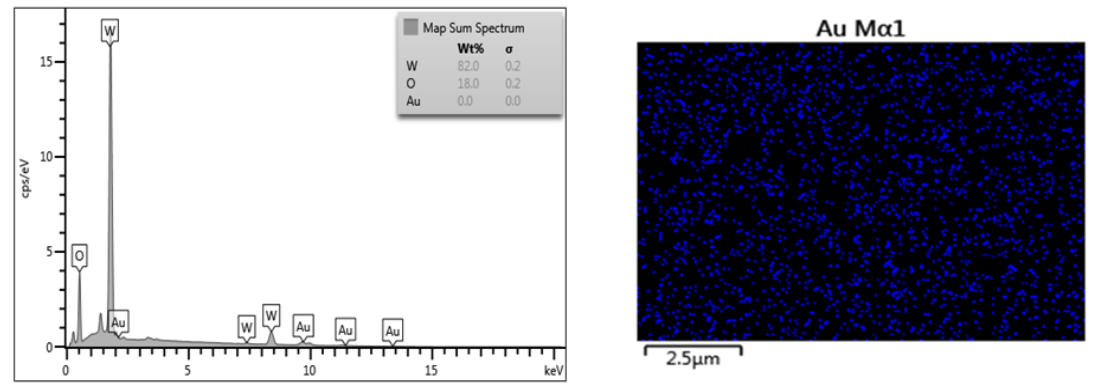

(a)
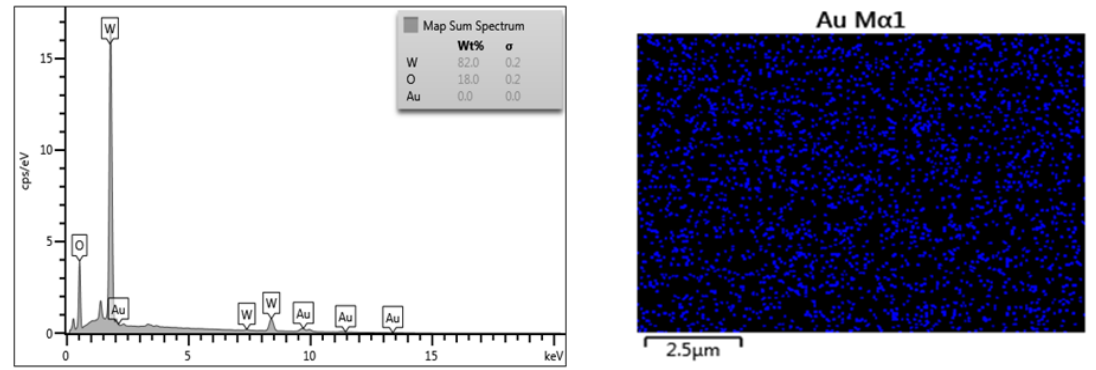

(b)

FIGURE 2. EDX spectra and mapping of (a) $\mathrm{WO}_{3} / \mathrm{Au}$ (1s) and (b) $\mathrm{WO}_{3} / \mathrm{Au}(5 \mathrm{~s})$

UV-Vis absorption spectroscopy was employed to estimate the optical band gap $\left(\mathrm{E}_{\mathrm{g}}\right)$ of the $\mathrm{WO}_{3}$ films with different $\mathrm{Au}$ nanoparticles loading. From the spectra (Figure 3), all the $\mathrm{WO}_{3}$ samples absorbed light with a wavelength smaller than $475 \mathrm{~nm}$. This indicated that the band gap energy of the $\mathrm{WO}_{3}$ produced is $\sim 2.6 \mathrm{eV}$ and it is similar with previous reports (Rao et al. 2014; Yang et al. 2015). Meanwhile, the Au nanoparticles on the FTO glass substrate showed a plasmonic absorption at $560 \mathrm{~nm}$ (inset of Figure 3). However, no obvious UV-Vis absorption of Au nanoparticles on $\mathrm{WO}_{3}$ samples was observed and this may be due to the low amount of Au loading. The peaks above $450 \mathrm{~nm}$ are interference fringes commonly observed for $\mathrm{WO}_{3}$ sample (Amer et al. 2019; Johansson et al. 2012). Tauc plot of $\left(\alpha \mathrm{h}_{\mathrm{v}}\right)^{0.5}$ vs energy was plotted (Figure $3(\mathrm{~b})$ ) where an extrapolation was made by drawing a straight line along the linear portion of curves to the x-axis. The intercept between the $\mathrm{x}$-axis with the straight line gives the optical band gap value. From the extrapolation, the band gaps of all samples are the same, which was found to be $\sim 2.6 \mathrm{eV}$. The Au loading does not affect the band gap of $\mathrm{WO}_{3}$ film.
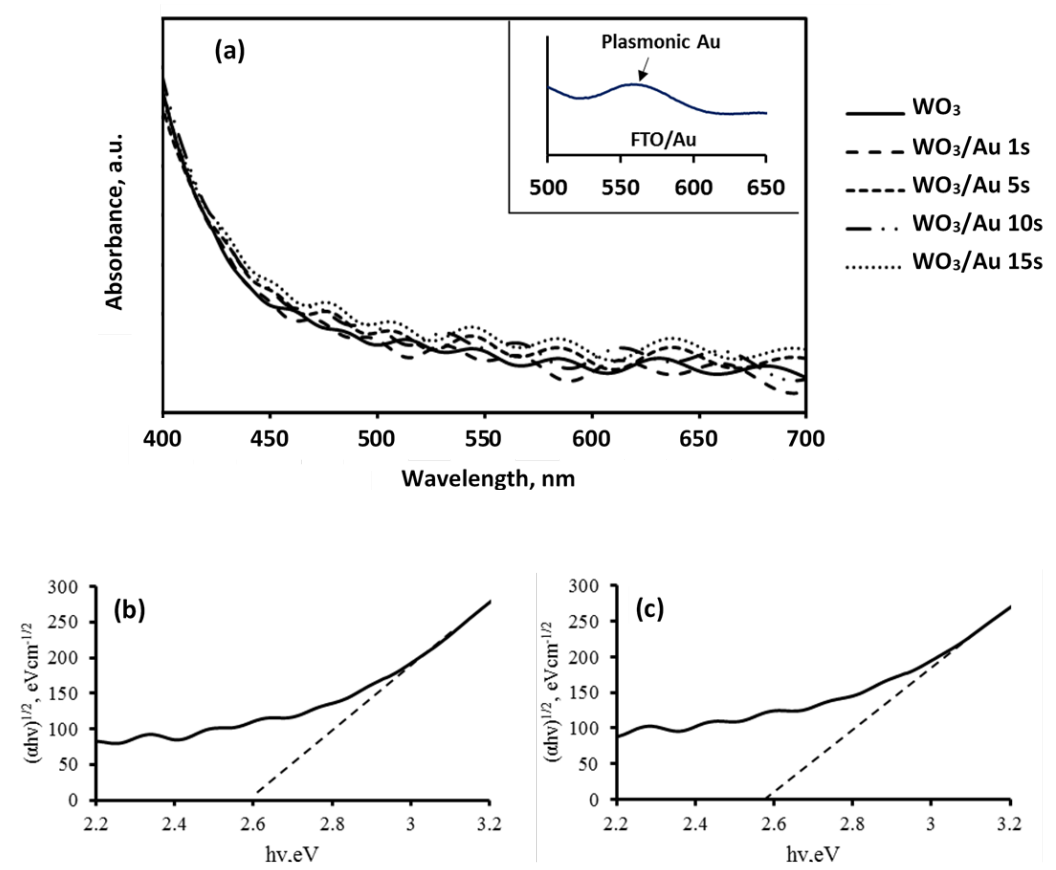

FIGURE 3. (a) UV-Vis spectra of $\mathrm{WO}_{3}$ and $\mathrm{WO}_{3} / \mathrm{Au} 1,5,10$ and $15 \mathrm{~s}$ electrodeposition time of Au. (b) Tauc plots of $\mathrm{WO}_{3} / \mathrm{Au}(1 \mathrm{~s})$ and (c) $\mathrm{WO}_{3} / \mathrm{Au}(15 \mathrm{~s})$ 
Photocurrent measurement of photoelectrode were carried out in conventional three electrode systems under $100 \mathrm{~mW} / \mathrm{cm}^{2}$ simulated solar light. The photocurrent density versus applied potential was obtained by employing linear sweep voltammograms (Figure 4(a)). Anodic photocurrent suggested that the $\mathrm{WO}_{3}$ and $\mathrm{WO}_{3} / \mathrm{Au}$ photoelectrodes are serving as photoanodes. Apparently, the addition of Au nanoparticles on the $\mathrm{WO}_{3}$ surface improve the photocurrent generation without affecting the I/V profile of the $\mathrm{WO}_{3}$. This suggested that the photocatalytic behavior of the $\mathrm{WO}_{3}$ photoelectrode remained. The highest photocurrent generation was achieved by $\mathrm{WO}_{3} /$ $\mathrm{Au}$ (1s) photoelectrode. As the Au nanoparticles can serve as a catalyst in oxygen evolution reaction (OER), they can mediate and improve the rate of the hole transfer from $\mathrm{WO}_{3}$ to water (Cheng 2015). The holes from the $\mathrm{WO}_{3}$ will be injected into the Au nanoparticles, and transferred to the electrode/electrolyte interface, with a prolonged lifetime of photogenerated electron-hole pairs. Thus, the addition of $\mathrm{Au}$ loading enhanced the photoactivity of the $\mathrm{WO}_{3}$ photocatalyst. Meanwhile, higher Au loading leads to the decrease of photocurrent generation. The $\mathrm{Au}$ nanoparticles may have covered the photoactive sites of the photocatalyst which hinders the contact between the photoactive sites with the electrolytes (Lui et al. 2019; Zhang et al. 2015). Moreover, the excess of Au loading will serve as electron-hole recombination center (Haro et al. 2014; Jun et al. 2020).

(a)

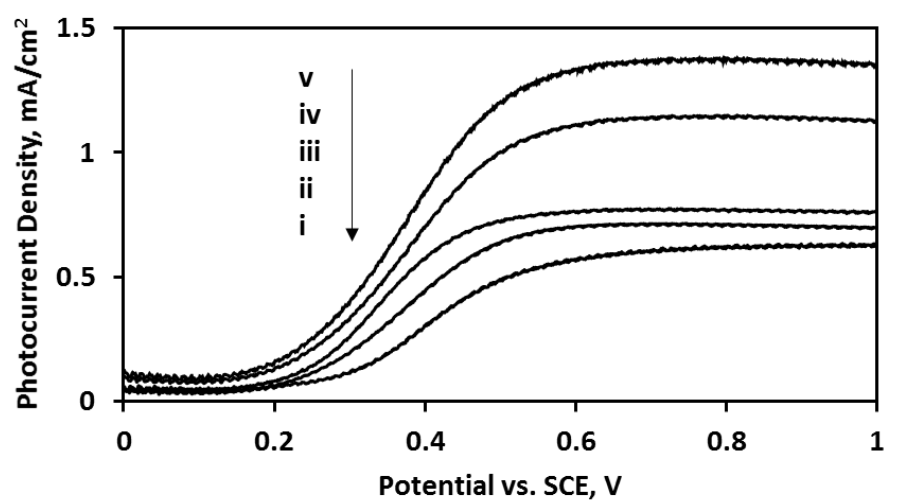

(b)

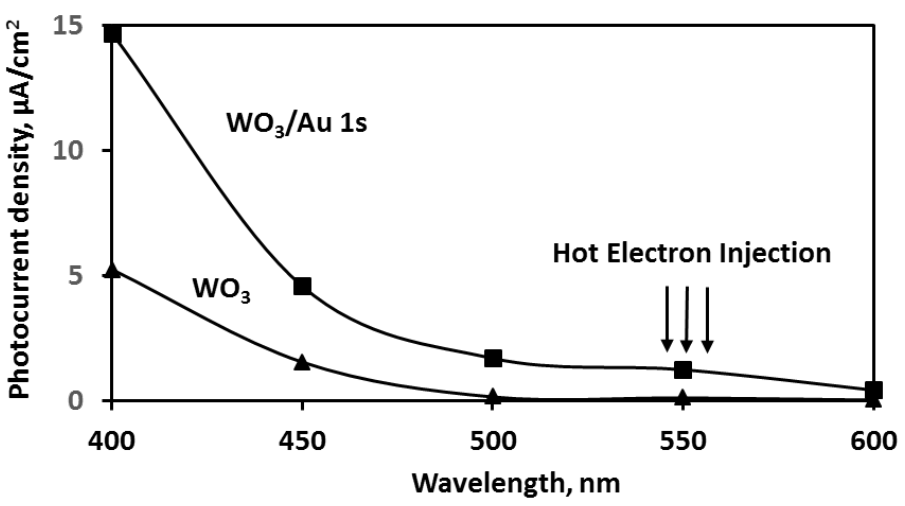

FIGURE 4. (a) Photoelectrochemical performance of (i) $\mathrm{WO}_{3}$ and $\mathrm{WO}_{3} / \mathrm{Au}$ with (ii) 15, (iii) 10 (iv) 5 and (v) $1 \mathrm{~s}$ electrodeposition time of Au. (b) Photocurrent generation of $\mathrm{WO}_{3}$ and $\mathrm{WO}_{3} / \mathrm{Au}(1 \mathrm{~s})$ at $1.0 \mathrm{~V}$ vs SCE

To understand the plasmonic behavior of $\mathrm{Au}$ nanoparticles on the $\mathrm{WO}_{3}$ surface, photoelectrochemical tests were also carried out with several wavelength cut-off filters. The bare $\mathrm{WO}_{3}$ photoelectrode generated photocurrent with the light irradiation $<500 \mathrm{~nm}$ (Figure 4(b)). This is due to the band gap of $\mathrm{WO}_{3}$ which only allows the light absorption at this region (as discussed in UV-Vis part). With the presence of Au nanoparticles, the photocurrent generation was extended to $600 \mathrm{~nm}$. This was due to the plasmonic enhancement of photocatalytic water splitting reaction. 
There are three mechanisms suggested to explain the plasmonic effect on photocatalytic water-splitting reaction (Mi et al. 2016). They are: light scattering effect, hot electron injection, and plasmon resonance energy transfer (PRET). Based on the previous studies, the light scattering effect can only be detectable when the size of the Au nanoparticles is larger than $50 \mathrm{~nm}$ (Zhang et al. 2014). In this work, the size of the electrodeposited $\mathrm{Au}$ nanoparticles is less than $50 \mathrm{~nm}$. Therefore, only hot electron injection and PRET mechanisms may contribute to the significant improvement of photocurrent generation in $\mathrm{WO}_{3} / \mathrm{Au}$ photoelectrodes.

In the hot electron injection mechanism (Figure 5(a)), the hot electrons generated during the light irradiation was injected into the conduction band of $\mathrm{WO}_{3}$. Together with the electron generated by the $\mathrm{WO}_{3}$, they travel across the external circuit and reduce the $\mathrm{H}^{+}$ions at the Pt cathode. Meanwhile, for the PRET mechanism (Figure 5(b)), the plasmonic resonance of Au nanoparticles enhance the electromagnetic field of the neighboring $\mathrm{WO}_{3}$, resulting in enhanced generation of electron-hole pairs. Thus, more electrons are generated and travel across the external circuit to reduce $\mathrm{H}^{+}$ions. Here, it is possible that both hot electron injection mechanism and the PRET mechanism happened. This is because the $\mathrm{WO}_{3} /$ Au photoelectrode generated a much higher photocurrent density in the wavelength range of 500-600 nm (Figure $5(b))$, as well as in the range of smaller wavelength $(<450$ $\mathrm{nm}$ ) where the band edge absorption of $\mathrm{WO}_{3}$ and the plasmonic absorption of Au nanoparticles overlapped ( $\mathrm{Ng}$ et al. 2017; Ye et al. 2017).

(a)

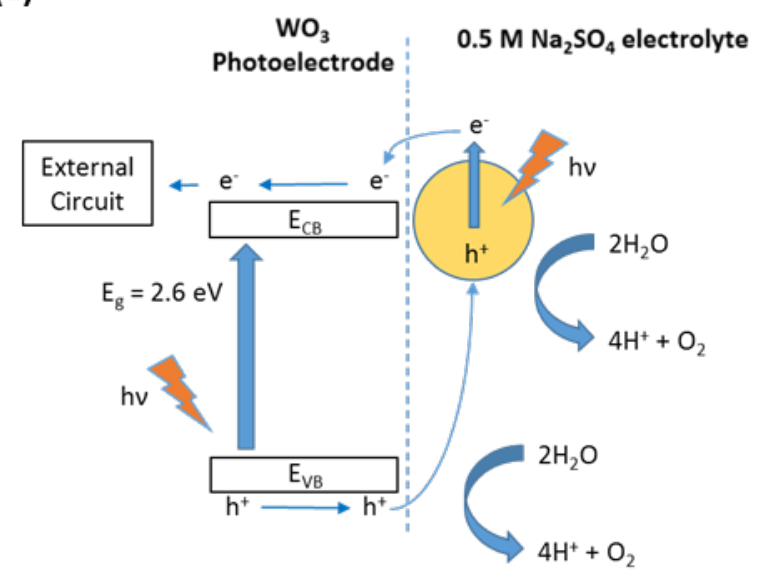

(b)

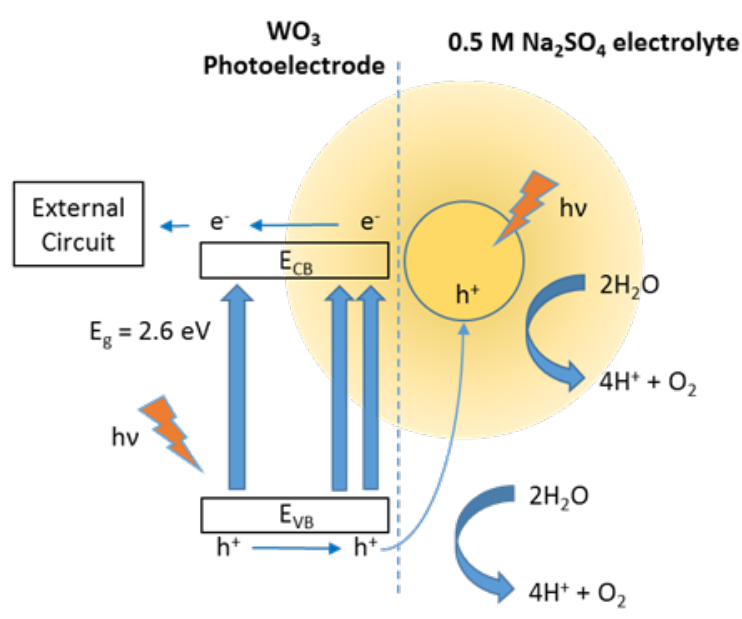

FIGURE 5. Plasmonic enhancement of $\mathrm{WO}_{3} / \mathrm{Au}$ via (a) hot electron injection and (b) plasmon resonance energy transfer (PRET) mechanism 
The Au-modified $\mathrm{WO}_{3}$ photoelectrodes were also tested for photodegradation of organic compounds. In this study, methanol and formic acid were used as they are the simplest organic compounds with one carbon atom. The photocurrent generation was summarized in Table 1. In the presence of organic compounds, we found that the $\mathrm{I} / \mathrm{V}$ profile of the $\mathrm{WO}_{3}$ remained similar, but a higher photocurrent density was recorded. These organic compounds tend to be oxidized more easily compared to water. Therefore, they can serve as hole scavengers which consumes the photogenerated holes in photoanodes and prevents the electron-holes recombination. Slower rate of recombination allows more electrons available to be transported to the cathode (Zhang et al. 2007). Thus, the efficiency of the photocatalyst in the production of $\mathrm{H}_{2}$ will be improved. Without the presence of $\mathrm{O}_{2}$, the degradation of these compounds will produce $\mathrm{H}^{+}$ions and $\mathrm{CO}_{2}$ gas, and the $\mathrm{H}^{+}$will be reduced at the cathode to form $\mathrm{H}_{2}$. The overall reactions as follow (Oros-Ruiz et al. 2013):

$$
\begin{gathered}
\mathrm{CH}_{3} \mathrm{OH}_{\text {(liq) }} \rightarrow \mathrm{H}_{2} \mathrm{CO}_{\text {(gas) }}+\mathrm{H}_{2 \text { (gas) }} \\
\mathrm{H}_{2} \mathrm{CO}_{\text {(gas) }}+\mathrm{H}_{2} \mathrm{O}_{\text {(liq) }} \rightarrow \mathrm{H}_{2} \mathrm{CO}_{2 \text { (liq) }}+\mathrm{H}_{2 \text { (gas) }} \\
\mathrm{H}_{2} \mathrm{CO}_{2 \text { (liq) }} \rightarrow \mathrm{CO}_{2 \text { (gas) }}+\mathrm{H}_{2 \text { (gas) }}
\end{gathered}
$$

We also noticed that the photocurrent generation from the degradation of formic acid was higher compared to that of methanol. This might be due to the formic acid $\left(\mathrm{pK}_{\mathrm{a}}=3.75\right)$ (Kim et al. 1996) is more readily to deprotonate compared to methanol $\left(\mathrm{pK}_{\mathrm{a}}=15.5\right)$ (Zhu et al. 2009). As a result, the deprotonated formate ions that carry negative charge may be attracted to the surface of $\mathrm{WO}_{3}$, and oxidized by the positive holes. Hence, higher

\begin{tabular}{|c|c|c|c|c|}
\hline \multirow{2}{*}{ Photoelectrodes } & \multirow{2}{*}{$\begin{array}{l}\text { Charge density*, } \mathrm{mC} / \\
\qquad \mathrm{cm}^{2}\end{array}$} & \multicolumn{3}{|c|}{ Photocurrent density**, $\mathrm{mA} / \mathrm{cm}^{2}(1.0 \mathrm{~V} / \mathrm{SCE})$} \\
\hline & & Without donor & 1.0 M Methanol & 1.0 M Formic acid \\
\hline $\mathrm{WO}_{3}$ & - & 0.61 & 1.53 & 2.00 \\
\hline $\mathrm{WO}_{3} / \mathrm{Au}(1 \mathrm{~s})$ & 0.0255 & 1.35 & 2.90 & 3.74 \\
\hline $\mathrm{WO}_{3} / \mathrm{Au}(5 \mathrm{~s})$ & 0.0833 & 1.13 & 1.95 & 3.02 \\
\hline $\mathrm{WO}_{3} / \mathrm{Au}(10 \mathrm{~s})$ & 0.1444 & 0.76 & 1.61 & 2.07 \\
\hline $\mathrm{WO}_{3} / \mathrm{Au}(15 \mathrm{~s})$ & 0.1833 & 0.70 & 1.46 & 1.95 \\
\hline
\end{tabular}
photocurrent generation was recorded.

TABLE 1. The effect of Au nanoparticles loading towards the photoelectrochemical properties of the $\mathrm{WO}_{3}$ photoanodes

*The total charge density recorded during the electrodeposition of Au nanoparticles at $0.245 \mathrm{~V}$ vs. SCE

$* * 0.5 \mathrm{M} \mathrm{Na}_{2} \mathrm{SO} 4$ as supporting electrolyte

\section{CONCLUSION}

In this study, we investigated the plasmonic behavior of $\mathrm{Au}$ nanoparticles on the $\mathrm{WO}_{3}$ photoelectrode for water splitting reaction. The photocurrent improved $>100 \%$ with a minimal amount of Au loading. This is suggested to be attributed by the hot electron injection and plasmon resonance energy transfer effects, which enhanced charge generation of the $\mathrm{WO}_{3}$ photoelectrode. The photocurrent generation was further improved with the addition of sacrificial donors. It achieved $3.74 \mathrm{~mA} /$ $\mathrm{cm}^{2}$ when $1.0 \mathrm{M}$ of formic acid was added.

\section{ACKNOWLEDGEMENTS}

The authors would like to thank Universiti Kebangsaan Malaysia for providing the facilities and research grant GUP-2017-065 and PP-SELFUEL-2020.

\section{REFERENCES}

Alenzi, N., Liao, W.S., Cremer, P.S., Sanchez-Torres, V., Wood, T.K., Ehlig-Economides, C. \& Cheng, Z. 2010. Photoelectrochemical hydrogen production from water/ methanol decomposition using $\mathrm{Ag} / \mathrm{TiO}_{2}$ nanocomposite thin films. International Journal of Hydrogen Energy 35(21): 11768-11775. 
Amer, M.S., Arunachalam, P., Al-Mayouf, A.M., Prasad, S., Alshalwi, M.N. \& Ghanem, M.A. 2019. Mesoporous tungsten trioxide photoanodes modified with nitrogen-doped carbon quantum dots for enhanced oxygen evolution photo-reaction. Nanomaterials 9(10): 1502.

Aslam, M., Ismail, I.M.I., Chandrasekaran, S. \& Hameed, A. 2014. Morphology controlled bulk synthesis of disc-shaped $\mathrm{WO}_{3}$ powder and evaluation of its photocatalytic activity for the degradation of phenols. Journal Hazardous Materials 276: 120-128.

Chakrapani, V., Thangala, J. \& Sunkara, M.K. 2009. $\mathrm{WO}_{3}$ and $\mathrm{W}_{2} \mathrm{~N}$ nanowire arrays for photoelectrochemical hydrogen production. International Journal of Hydrogen Energy 34(22): 9050-9059.

Chen, L., Tian, L., Zhao, X., Hu, Z., Fan, J. \& Lv, K. 2020a. SPR effect of $\mathrm{Au}$ nanoparticles on the visible photocatalytic $\mathrm{RhB}$ degradation and $\mathrm{NO}$ oxidation over $\mathrm{TiO} 2$ hollow nanoboxes. Arabian Journal of Chemistry 13(2): 44044416.

Chen, Y., Feng, X., Liu, Y. Guan, X., Burda, C. \& Guo, L. 2020b. Metal oxide-based tandem cells for self-biased photoelectrochemical water splitting. ACS Energy Letters 5(3): 844-866.

Cheng, Y. 2015. Advances in electrocatalysts for oxygen evolution reaction of water electrolysis-from metal oxides to carbon nanotubes. Progress in Natural Science: Materials International 25(6): 545-553.

Fujishima, A. \& Honda, K. 1972. Electrochemical photolysis of water at a semiconductor electrode. Nature 238(5358): 37-38.

Han, S., Li, J., Chen, X., Huang, Y., Liu, C., Yang, Y. \& Li, W. 2012. Enhancing photoelectrochemical activity of nanocrystalline $\mathrm{WO}_{3}$ electrodes by surface tuning with $\mathrm{Fe}(\mathrm{III})$. International Journal of Hydrogen Energy 37(22): 16810-16816.

Haro, M., Abargues, R., Herraiz-Cardona, I., Martínez-Pastor, J. \& Giménez, S. 2014. Plasmonic versus catalytic effect of gold nanoparticles on mesoporous $\mathrm{TiO}_{2}$ electrodes for water splitting. Electrochimica Acta 144: 64-70.

Hong, S.J., Lee, S., Jang, J.S. \& Lee, J.S. 2011. Heterojunction $\mathrm{BiVO}_{4} / \mathrm{WO}_{3}$ electrodes for enhanced photoactivity of water oxidation. Energy \& Environmental Science 4(5): 1781-1787.

Hu, D., Diao, P., Xu, D. \& Wu, Q. 2016. Gold/WO nanocomposite photoanodes for plasmonic solar water splitting. Nano Research 9(6): 1735-1751.

Jana, S.K., Majumder, T. \& Banerjee, S. 2014. Enhanced photoelectrochemical property of gold nanoparticle sensitized $\mathrm{TiO}_{2}$ nanotube: A crucial investigation at electrodeelectrolyte interface. Journal of Electroanalytical Chemistry 727: 99-103.

Johansson, M.B., Niklasson, G.A. \& Österlund, L. 2012. Structural and optical properties of visible active photocatalytic $\mathrm{WO}_{3}$ thin films prepared by reactive dc magnetron sputtering. Journal of Materials Research 27(24): 3130-3140.

Jun, J., Ju, S., Moon, S., Son, S., Huh, D., Liu, Y., Kim, K. \& Lee, H. 2020. The optimization of surface morphology of Au nanoparticles on $\mathrm{WO}_{3}$ nanoflakes for plasmonic photoanode. Nanotechnology 31(20): 204003.
Kim, M.H., Kim, C.S., Lee, H.W. \& Kim, K. 1996. Temperature dependence of dissociation constants for formic acid and 2,6-dinitrophenol in aqueous solutions up to $175^{\circ} \mathrm{C}$. Journal of the Chemical Society, Faraday Transactions 92(24): 4951-4956.

Kwong, W.L., Savvides, N. \& Sorrell, C.C. 2012. Electrodeposited nanostructured $\mathrm{WO}_{3}$ thin films for photoelectrochemical applications. Electrochimica Acta 75: 371-380.

Lee, J.Y. \& Jo, W.K. 2016. Heterojunction-based twodimensional $\mathrm{N}$-doped $\mathrm{TiO}_{2} / \mathrm{WO}_{3}$ composite architectures for photocatalytic treatment of hazardous organic vapor. Journal Hazardous Materials 314: 22-31.

Li, J. \& Wu, N. 2015. Semiconductor-based photocatalysts and photoelectrochemical cells for solar fuel generation: A review. Catalysis Science \& Technology 5(3): 1360-1384.

Li, Y., Yu, H., Zhang, C., Fu, L., Li, G., Shao, Z. \& Yi, B. 2013a. Enhancement of photoelectrochemical response by $\mathrm{Au}$ modified in $\mathrm{TiO}_{2}$ nanorods. International Journal of Hydrogen Energy 38(29): 13023-13030.

Li, Z., Luo, W., Zhang, M., Feng, J. \& Zou, Z. 2013b. Photoelectrochemical cells for solar hydrogen production: Current state of promising photoelectrodes, methods to improve their properties, and outlook. Energy \& Environmental Science 6(2): 347-370.

Lianos, P. 2011. Production of electricity and hydrogen by photocatalytic degradation of organic wastes in a photoelectrochemical cell: the concept of the photofuelcell: A review of a re-emerging research field. Journal Hazardous Materials 185(2-3): 575-590.

Lui, Y., Chang, Y.S., Hsu, Y.J., Hwang, B.J. \& Hsueh, C.H. 2019. Fabrication of $\mathrm{WO}_{3}$ photoanode decorated with $\mathrm{Au}$ nanoplates and its enhanced photoelectrochemical properties. Electrochimica Acta 321: 134674.

Mi, Y., Wen, L., Xu, R., Wang, Z., Cao, D., Fang, Y. \& Lei, Y. 2016. Constructing a AZO/TiO2 core/shell nanocone array with uniformly dispersed Au NPs for enhancing photoelectrochemical water splitting. Advanced Energy Materials 6(1): 1501496.

Minggu, L.J., Daud, W.R.W. \& Kassim, M.B. 2010. An overview of photocells and photoreactors for photoelectrochemical water splitting. International Journal of Hydrogen Energy 35(11): 5233-5244.

Minggu, L.J., Ng, K.H., Kadir, H.A. \& Kassim, M.B. 2014. Bilayer $n-\mathrm{WO}_{3} / \mathrm{p}-\mathrm{Cu}_{2} \mathrm{O}$ photoelectrode with photocurrent enhancement in aqueous electrolyte photoelectrochemical reaction. Ceramics International 40(10): 16015-16021.

Ng, K.H., Minggu, L.J., Jaafar, N.A. \& Kassim, M.B. 2018. Plasmonic resonance effect of aurum on photoelectrochemical performance of $\mathrm{Cu}_{2} \mathrm{O}$ photocathode. Sains Malaysiana 47(7): 1511-1516.

Ng, K.H., Minggu, L.J., Jaafar, N.A., Arifin, K. \& Kassim, M.B. 2017. Enhanced plasmonic photoelectrochemical response of Au sandwiched $\mathrm{WO}_{3}$ photoanodes. Solar Energy Materials and Solar Cells 172: 361-367.

Ng, K.H., Minggu, L.J. \& Kassim, M.B. 2013. Galliumdoped tungsten trioxide thin film photoelectrodes for photoelectrochemical water splitting. International Journal of Hydrogen Energy 38(22): 9585-9591. 
Nishanthi, S.T., Iyyapushpam, S., Sundarakannan, B., Subramanian, E. \& Padiyan, D.P. 2015. Plasmonic silver nanoparticles loaded titania nanotube arrays exhibiting enhanced photoelectrochemical and photocatalytic activities. Journal of Power Sources 274: 885-893.

Oros-Ruiz, S., Zanella, R., López, R., Hernández-Gordillo, A. \& Gómez, R. 2013. Photocatalytic hydrogen production by water/methanol decomposition using $\mathrm{Au} / \mathrm{TiO}{ }_{2}$ prepared by deposition-precipitation with urea. Journal Hazardous Materials 263: 2-10.

Peerakiatkhajohn, P., Butburee, T., Yun, J.H., Chen, H., Richards, R.M. \& Wang, L. 2015. A hybrid photoelectrode with plasmonic Au@ $\mathrm{TiO}_{2}$ nanoparticles for enhanced photoelectrochemical water splitting. Journal of Materials Chemistry A 3(40): 20127-20133.

Rao, P.M., Cai, L., Liu, C., Cho, I.S., Lee, C.H., Weisse, J.M., Yang, P. \& Zheng, X. 2014. Simultaneously efficient light absorption and charge separation in $\mathrm{WO}_{3} / \mathrm{BiVO}_{4}$ core/ shell nanowire photoanode for photoelectrochemical water oxidation. Nano Letters 14(2): 1099-1105.

Raptis, D., Dracopoulos, V. \& Lianos, P. 2017. Renewable energy production by photoelectrochemical oxidation of organic wastes using $\mathrm{WO}_{3}$ photoanodes. Journal of Hazardous Materials 333: 259-264.

Sheng, C., Wang, C., Wang, H., Jin, C., Sun, Q. \& Li, S. 2017. Self-photodegradation of formaldehyde under visible-light by solid wood modified via nanostructured Fe-doped $\mathrm{WO}_{3}$ accompanied with superior dimensional stability. Journal Hazardous Materials 328: 127-139.

Tee, S.Y., Win, K.Y., Teo, W.S., Koh, L.D., Liu, S., Teng, C.P. \& Han, M.Y. 2017. Recent progress in energy-driven water splitting. Advanced Science 4(5): 1600337.

Verma, A., Srivastav, A., Banerjee, A., Sharma, D., Sharma, S., Singh, U.B., Satsangi, V.R., Shrivastav, R., Avasthi, D.K. \& Dass, S. 2013. Plasmonic layer enhanced photoelectrochemical response of $\mathrm{Fe}_{2} \mathrm{O}_{3}$ photoanodes. Journal of Power Sources 315: 152-160.

Verma, P., Kuwahara, Y., Mori, K. \& Yamashita, H. 2016. Pd/Ag and $\mathrm{Pd} / \mathrm{Au}$ bimetallic nanocatalysts on mesoporous silica for plasmon-mediated enhanced catalytic activity under visible light irradiation. Journal of Materials Chemistry A 4(26): 10142-10150.

Wang, Y., Chen, K.S., Mishler, J., Cho, S.C. \& Adroher, X.C. 2011. A review of polymer electrolyte membrane fuel cells: Technology, applications, and needs on fundamental research. Applied Energy 88(4): 981-1007.

Yan, J., Wu, H., Li, P., Chen, H., Jiang, R. \& Liu, S.F. 2017. $\mathrm{Fe}(\mathrm{III})$ doped $\mathrm{NiS}_{2}$ nanosheet: A highly efficient and lowcost hydrogen evolution catalyst. Journal of Materials Chemistry A 5(21): 10173-10181.
Yang, Y., Xie, R., Liu, Y., Li, J. \& Li, W. 2015. Effect of surface passivation on photoelectrochemical water splitting performance of $\mathrm{WO}_{3}$ vertical plate-like films. Catalysts 5(4): 2024-2038.

Ye, W., Long, R., Huang, H. \& Xiong, Y. 2017. Plasmonic nanostructures in solar energy conversion. Journal of Materials Chemistry C 5(50): 1008-1021.

Zhang, L., Herrmann, L.O. \& Baumberg, J.J. 2015. Size dependent plasmonic effect on $\mathrm{BiVO}_{4}$ photoanodes for solar water splitting. Scientific Reports 5: 16660.

Zhang, L., Lin, C.Y., Valev, V.K., Reisner, E., Steiner, U. \& Baumberg, J.J. 2014. Plasmonic enhancement in $\mathrm{BiVO}_{4}$ photonic crystals for efficient water splitting. Small 10(19): 3970-3978.

Zhang, X. \& Tang, A. 2012. Novel $\mathrm{CuO} / \mathrm{TiO}_{2}$ nanocomposite films with a graded band gap for visible light irradiation. Materials Express 2(3): 238-244.

Zhang, Z., Yuan, Y., Fang, Y., Liang, L., Ding, H., Shi, G. \& Jin, L. 2007. Photoelectrochemical oxidation behavior of methanol on highly ordered $\mathrm{TiO}_{2}$ nanotube array electrodes. Journal of Electroanalytical Chemistry 610(2): 179-185.

Zhang, X., Lu, X., Shen, Y., Han, J., Yuan, L., Gong, L., Xu, Z., Bai, X., Wei, M., Tong, Y., Gao, Y., Chen, J., Zhou, J. \& Wang, Z.L. 2011. Three-dimensional $\mathrm{WO}_{3}$ nanostructures on carbon paper: Photoelectrochemical property and visible light driven photocatalysis. Chemical Communications 47(20): 5804-5806.

Zhu, J., Li, W., Li, J., Li, Y., Hu, H. \& Yang, Y. 2013. Photoelectrochemical activity of $\mathrm{NiWO}_{4} / \mathrm{WO}_{3}$ heterojunction photoanode under visible light irradiation. Electrochimica Acta 112: 191-198.

Zhu, L., Gamez, G., Chen, H., Chingin, K. \& Zenobi, R. 2009. Rapid detection of melamine in untreated milk and wheat gluten by ultrasound-assisted extractive electrospray ionization mass spectrometry (EESI-MS). Chemical Communications 5: 559-561.

Zhu, W., Liu, J., Yu, S., Zhou, Y. \& Yan, X. 2016. Ag loaded $\mathrm{WO}_{3}$ nanoplates for efficient photocatalytic degradation of sulfanilamide and their bactericidal effect under visible light irradiation. Journal Hazardous Materials 318: 407-416.

Fuel Cell Institute

Universiti Kebangsaan Malaysia

43600 UKM Bangi, Selangor Darul Ehsan

Malaysia

*Corresponding author; email: lorna_jm@ukm.edu.my

Received: 17 August 2020

Accepted: 11 September 2020 